\title{
Social criticism in the short stories anthology "Saksi Mata" by Seno Gumira Ajidarma
}

\author{
Muhammad Rizki Asrul ${ }^{1}$, Yasnur Asri \\ \{mrasrul1994@gmail.com ${ }^{1}$, yasnurasri5@gmail.com $\left.{ }^{2}\right\}$ \\ ${ }^{1,2}$ Universitas Negeri Padang, Indonesia
}

\begin{abstract}
This study aims to: (1) describe the social problems in the short stories anthology "Saksi Mata" by Seno Gumira Ajidarma, (2) describe the form of criticism by the author in athe short stories anthology "Saksi Mata" by Seno Gumira Ajidarma. This type of research is qualitative research using a descriptive method of content analysis. The results of this research are in the form of social problems contained in the short stories anthology "Saksi Mata" by Seno Gumira Ajidarma, namely: (a) the problem of crime, (b) the problem of population, (c) the problem of war, (d) the problem of bureaucracy. Furthermore, the form of criticism by the author in athe short stories anthology "Saksi Mata" by Seno Gumira Ajidarma, namely: (a) directly, (b) cynical, (c) humor, (d) interpretative, (e) symbolic.
\end{abstract}

Keywords: Social criticism, short stories, saksi mata

\section{Introduction}

Literary works basically contains about issues surrounding social life. Literary presents a description of life; and life itself is a social reality. In the literature, the writer shows his attitude and giving wisdom about various aspects of human life, no exeption about himself [1]-[5]. So literature has a major role in human life, exaggeration to say the literature is a social portrait that reveals the condition of society at a particular time. A literary work can provide a distinctive understanding on social conditions, culture, and ideology in certain societies.

Literary works comes from the creative process of the authors who combine a wide range of ideas, ideas, insight and feedback about things that exist in the life around it. Many forms of literary works created by the author in conveying ideas, ideas, understanding and including feedback about things that no life around it, one of which is of short stories. Indirectly, the reader can feel, appreciate and discover the problems of life offered by the author. That is why, many literary works including short stories is able to throw discourse unwittingly affect the views of readers. [6], [7]

Short story is a picture of a society that is expressed in an article, namely as a humanitarian issue, love, hope, protest, social inequality, religiosity, and so on. Short Story is one of the literary genre that has always been associated identity as a literary newspaper, the product literature that appeared in the print media in newspapers, in Indonesia.[7]-[9]

Social phenomenon in which terwacanakan short story shows no balance between the reality communities experiencing social and cultural change with the willingness and ability of the community. (Manuaba, 2009, p. 17), short stories also reflect the values that consciously sought to be implemented by the community. In the creation of literary works, the authors discuss the many social problems that occur in the community. It is seen from each of the 
elements of a good story that characterization, setting, characterization and themes raised in it[10] Therefore, the problems that exist in society are often taken into account by the author.

Explains that the shift in social values that occurs and is experienced by the people is the idea for the author in the birth of a literary work. Basically, the literary work beneficial to human life. Through literature readers can weigh the problems, whether related to personal or group. In addition, through literature, poet convey the values of life as literary works created to be enjoyed, understood, and utilized by the community. Of social problems is exactly born a criticism in a literary work, usually in the form of criticism of the government policy, the issue of religion, households, schools, poverty and others.[3]

Social criticism is the response given by observation, comparison, and consideration of the social problems in life. Form of delivery of the criticism that can be either protest or criticism by individuals / groups to certain conditions that are not in accordance with the conditions of social life.The criticism contained in the literature may be limited to lifting a problem to the surface or is accompanied by a way out that is subjective. Social criticism in relation to the theme aims to arouse the conscience of the community in addressing irregularitiesirregularities committed by the authorities.

The development of the short story in Indonesia is quite rapid evidenced by the many new stories are published and the emergence of talented writers. Many authors vying social criticism voiced in the short story as a social problem is also growing. Because the writer is a party committed to improving human dignity through the representation of social reality in literary works.[11] So much social criticism voiced a short story, a story writer who is often criticized in his writings is Seno Gumira Ajidarma.

Seno Gumira Ajidarma, born in Boston (USA), June 19, 1958 is an author, journalist, photographer, film critic Indonesia and faculty where education last one is Doctor of Letters at the University of Indonesia (2005) and received several awards in the field of authorship and literature such as the SEA Write Award (1987), Dinny O'Hearn For literary Prize (1997), Khatulistiwa literary Award (2005), and Ahmad Bakrie Award (2012). He was also known for her writing about the situation in East Timor. His writings about East Timor poured in a trilogy of books Saksi Mata (collection of short stories), Jazz, Parfum dan Insiden (roman), and Ketika Jurnalisme Dibungkam, Sastra Harus Bicara (essays). Until now Seno has produced numerous short stories published in some mass media. Study authored short stories was selected as the best short stories Kompas (1993). Book of short stories, among others: Manusia Kamar (1988), Penembak Misterius (1993), Saksi Mata (1994), Dilarang Menyanyi di Kamar Mandi (1995), Sebuah Pertanyaan untuk Cinta (1996), Iblis Tidak Pernah Mati (1999). Now Seno became rector at the Jakarta Arts Institute since 2016. [12]

A background as a journalist who made a lot Seno convey social criticism in any of his writings. Seno Gumira Ajidarma make literature as resistance to the curb symbolic space. Seno Gumira Ajidarma also try skinning symbolic world around them through fiction. Famous credo, when silenced journalism, literature must speak into a force against fate when working journalism symbolic world that preach the truth is manipulated, even covered by any attempt by the regime. [13] Such criticism was also presented by Seno Gumira Ajidarma in the book collection of Witness.

Witnesses of the book collection is composed of 16 (sixteen) and between one and the other short stories are interrelated and have a common thread on social issues. Cliff is among other things, Saksi Mata, Telinga, Manuel, Maria, Salvador, Rosario, Listrik, Pelajaran Sejarah, Misteri Kota Ningi (atawa The Invisible Cristmas), Klandestrin, Darah itu Merah, Jendral, Seruling Kesunyian, Salazar, Junior, Kepala di Pagar Da Silva, and Sebatang Pohon di Luar Desa.In addition, the short stories are interesting to study because of the short stories 
are laden with critiques delivered by the author. The number of social criticism expressed in a collection of short stories author Eyewitness Gumira Ajidarma Seno, such as criticism of the problems of poverty, crime, population, war, and unfair treatment by the government. That is one reason researchers determined the social criticism in a short stories anthology "Saksi Mata” by Seno Gumira Ajidarma.

\section{Method}

This type of research is qualitative research and using descriptive analysis method. Descriptive method is a method in researching the status of a group of people, an object, a set of conditions, a system of thought or a class of events in the present. The purpose of this descriptive study was to make decryption, picture or painting in a systematic, factual and accurate information on the facts, nature and the relationship between the phenomenon investigated.

\section{Results and Discussion}

In this section, described the research findings and discussion. The findings of the study contains a description of the social criticism in a short stories "Saksi Mata" by Seno Gumira Ajidarma.

\section{1. result}

Based on the findings Penalitian on social criticism in a collection of short stories Eyewitness Seno Gumira Ajidarma will discuss: (1) social problems in the short stories anthology "Saksi Mata" by Seno Gumira Ajidarma, (2) form of criticism by the author in athe short stories anthology "Saksi Mata" by Seno Gumira Ajidarma.

Read a short story collection Saksi Mata by Seno Gumira Ajidarma can be an afterthought for the reader to know the social problems that occur in the life of society and state and motivates readers to be better in life. As for the social criticism in a collection of short stories by Seno Gumira Eyewitness Ajidarma are as follows. (1) problem of evil, (2) problems of population, (3) problem of war, (4) problem of bureaucracy.

Table 1. Social problems

\begin{tabular}{lll}
\hline Number & Social Problems & $\begin{array}{l}\text { Amount } \\
\text { data }\end{array}$ \\
\hline 1 & Problem of Evil & 7 \\
2 & Problem of Population & 4 \\
3 & Problems of War & 16 \\
4 & Problems of Bureaucratic & 11 \\
\hline & total & 38 \\
\hline
\end{tabular}

From the use of the table above the author conveys four forms of social problems, namely the problem of crime, population problems, war issues, and bureaucratic problems. Of the four social problems, authors are more likely to convey problems of warfare and bureaucratic problems.

On the issue of crime here the authors convey the problems that violate legal norms. Forms of crime here is closely linked social organization, conflicts of ideology, politics. The crime problem can be seen in the following example. 
1) "Januario! They raped me, januario! I was stripped naked and my body was surrounded by clove cigarettes! I was put to sleep on the floor and my back was trampled with army shoes! My ears are ringing because of a rubber bat. It hurts so much, Januario! They put the table leg on my big toe and they stood on the table. I can not stand! They want your hiding place Januario! But how can I confess that you always keep your activities a secret? They don't believe that, Januario! I'm your girlfriend, your lover they think I would know! They raped me in turns! Eight people took turns raping me! It hurts so much, Januario! I can't stand it, Januario! After they raped, I was electrocuted, after being electrocuted I was raped. I can not hold it anymore! Moreover! When Domingos the bastard took turns rotating me. He whispered in my ear and claimed to really hate you. Isn't he a member of your movement, Januario? May God curse him! I can't do anything else, Januario. They drowned my body in the harbor with several other bodies. We will never see you again, Januario-remembers, remember me, Januario, in the name of love and love ..."

In the paragraph of the Listrik short story above, we can see the crimes committed by security officers by persecuting and raping the girlfriend of Januario. Januario's girlfriend is a victim to find out the hiding place of his girlfriend Januario. But the actions of the security officers there were too cruel and inhumane.

Further social problems which exist in the collection of short stories Witness is the population problem. The population problem is the reduction of population in an area. Can be seen in the following example.

2) In Ningi City I found something else altogether. In Ningi City, from year to year, the other population is decreasing. Very weird. When the world frowned at the horrifying rate of population growth, the City of Ningi was actually increasingly decreasing. When I rummaged through the archives, records in 1974 showed a total of 688,771 people. However, when I counted back in 1978 it turned out to be 329,271 people. Where did the 359,500 people go? Very weird. After all, it's not really a matter of shrinkage that makes me weird.

Here the author shows a population of data is always reduced every year. The problem presented by the authors is the high number of deaths in the region caused by the war that never ended.

On the issue of the war, the authors convey the problems that are difficult to resolve. The problem that resulted in many casualties both from the security forces and insurgents. But here the author more telling than the civilians who lost possessions, their families and their lives. Can be seen from the following example.

3) "AGE 5 years when the invasion took place. I heard explosions pounding from the harbor and smoke rising from behind the roofs of the houses. In front of the house I saw people running around in a panic. 'Warships shoot,' I hear someone screaming while running. I will never forget this atmosphere for the rest of my life, because since then our lives have been taken away. I don't know when true peace will come to our city again. "

At Manuel stories above paragraph, the author tells the material and moral impact of the war such as the destruction of people's homes there, people panicked and ran to and fro and atmosphere of war are so gripping that made peace in these areas is taken away. 
Recently the problem of bureaucracy. In this social problem pengaraang describe the kind of abuses committed by the authorities, which resulted into distress and suffering population. Biokrasi problem can be seen in the following example.

4) "We've been building this for decades," my guide said without being asked. "When the time comes, we will tear down everything that has been built up there, and emerge to replace it with a new system, which is better, truer and more robust."

Klandestin stories in the sentence above, the author tells about the shape of an uprising that would result from keseweng-handedness of the authorities there. The uprising that will happen aims to replace the new state system and free from any form of arbitrariness made by the authorities.

Table 2. Submission Form Criticism by Author

\begin{tabular}{lll}
\hline Number & Submission Forms Criticism & $\begin{array}{l}\text { Amount } \\
\text { data }\end{array}$ \\
\hline 1 & Directly & 6 \\
2 & Cynical & 11 \\
3 & humor & 6 \\
4 & interpretative & 9 \\
5 & symbolic & 6 \\
\hline & total & 38 \\
\hline
\end{tabular}

From the above table use the submission form of social criticism by the author is more balanced. Seno Gumira Ajidarma in a anthology of short stories "Saksi Mata" to use all forms of delivery of social criticism, namely the form of delivery in a straightforward, cynical, humor, interpretive and symbolic. Based on the form of delivery of such criticism, form criticism delivery of the authors of the most dominant in the collection of short stories is a form of delivery "Saksi Mata" cynical criticism of affirmation and criticism interpretive form of delivery.

Use of the form of delivery of a straightforward criticism in literary works the author shows expertise in exploring the language. Author of the short story anthology "Saksi Mata" tend to use criticism in a straightforward, direct, not with a symbol or allegory and not be connotative. Use of the form of delivery of criticism straightforwardly in a collection of short stories "Saksi Mata" serves to explain about something that wants to be emphasized and expressed through the use of direct language whose meaning straightforward, not with symbols or figurative and non connotative use of form submission criticism straightly by the author can be seen in the following examples.

1) Alfredo has long been killed. He was still 17 when the foreign soldier strafed him from behind. A year later Cornelio perished in bomb shards, when warplanes broke into the settlements of refugees and guerrillas in the forest. Stay Alfonso with him, moving in a clandestine organization in the city. However, Alfonso had left at the age of 30 years, he was shot while participating in a demonstration in front of the grave and brandishing banners that expressed their hearts.

Listrik sentence on the short story above describes the authors convey in a straightforward and direct criticism. How does the author tells a war experienced by Januario and killed his best friend and his friend Alfredo Cornelio very vicious and without further ado and making readers also feel how malignancies suffered by Alfredo and Cornelio. 
In the use of cynical forms of criticism, Seno Gumira Ajidarma in the collection of short stories "Saksi Mata" expressed criticism with anger and annoyance and dislike of life that was seen as bitter, full of suffering, and oppression on each of the problems presented in the short stories collection. The cynical form of criticism can be seen in the following example.

2) I send this ear to you, Dewi, as a memento from the battlefield. These are the ears of someone suspected of being an enemy spy. We are used to cutting off the ears of people who are suspected as a warning of the risks they face if they start a rebellion. Please accept this ear, just for you, I sent it from afar because I miss you. Every time you see these ears, remember me who is lonely. Cut the ear is the only entertainment.

Telinga fragment paragraph on the short story author tells a note in to the Goddess of her boyfriend on the battlefield. The notes contained in the sentence that tells how the goddess girlfriend send an ear of an alleged enemy. On the recordings author tells of suffering and oppression of someone who is considered an enemy by the very cruel and bitter but by not telling the story that is considered cruel by grumpy but treat it as an ordinary occurrence. That's what makes the story even more cruel and bitter.

In the use of cynical forms of criticism, Seno Gumira Ajidarma in the collection of short stories "Saksi Mata" expressed criticism with anger and annoyance and dislike of life that was seen as bitter, full of suffering, and oppression on each of the problems presented in the collection of short stories. The cynical form of criticism can be seen in the following example

3) "Eyewitness Brothers."

"Me, sir."

"Where are your eyes?"

"Taken by people, sir."

"Taken?"

"Me, sir."

"What do you mean by surgery?"

"No, sir. Taken with a spoon."

"Haa? Use Spoon? Why?"

"I don't know why, sir, but they say they want to be made tengkleng."

In the dialogue on the "Saksi Mata" short story between the Eye Witness and the Judge above, it can be seen from the characters from the Eye Witness who answer each question from the Judge very casually and as is. The eyewitness explained how his eyes were lost due to being diconkel by a group of people and would be made tengkleng. The use of words like "sendok" and "tengkleng" for the conversation between Eye Witness and Judge by the author made the trial that should be tense to be more relaxed and funny. But even though the conversation above seems funny, the author also inserts criticism of the wars that took place in the area that made innocent people lose their eyes.

The use of form criticism interpretive by the authors in the collection of short stories with the delivery Eyewitness be smooth and filled with meaning. Can be seen in the following example.

4) On the battlefield, Dewi's girlfriend is busy slaughtering people. All the soldiers sent to the battlefield have become very busy because everyone is fighting. Everyone is an enemy and everyone is worthy of suspicion. The rebels whispered the spirit of struggle, even into the ears of babies still in the womb.

In the sentence above Telinga short stories, the author describes a soldier (Dewi girlfriend) who is forced to kill the suspected enemy and no longer care that the person killed was 
actually an enemy or not. In those paragraphs fragment authors criticized rulers no longer care for humanity and human rights aspects.

Last use the symbolic form of delivery criticism. Here the author criticized figurative filled with meaning and symbolism. Use of the form of delivery of a symbolic criticism can be seen in the following example.

5) When the time comes, explosives that destroy the city buffer, the buffer of large buildings, the joints of state life, will make the city collapse, sink into the dark, hot earth, as hot as a burning crater of the mountain. Really a system to destroy the system. The giant well that was built with equipment, which has increasingly become more sophisticated, since hundreds of years ago, the depth has been tens of kilometers. The city will perish, disappear, as if it had never existed. In fact, archaeologists will not necessarily ever find it again.

In the paragraphs in the cliff Klandestin above, the author criticized with symbolism. An anti-government organization and do not agree to any system that has been built by the government. Here the author tells the organization that is ready to destroy all the joints of the state and will memepersiapkan themselves to offer resistance to the authorities.

\subsection{Discussion}

The results of the social criticism data analysis in the anthology of short stories "Saksi Mata" by Seno Gumira Ajidarma in the form of social problems and forms of delivery of criticism by the author. The social problems used by authors in the "Saksi Mata" anthology of short stories are 7 data crime problems, 4 data population problems, 16 data war issues, and data 7 bureaucratic problems. The form of submission of criticism by the authors in the "Saksi Mata" short story anthology is a form of straightforward delivery of data 6 directly, cynical 11 data, humorous 7 data, interpretive 9 data, and symbolic 6 data. The results of this study indicate that authors are more likely to use problems of war and bureaucratic problems and cynical forms of criticism.

The tendency of the delivery of social problems by the author is a way to convey criticism of social problems that occur a lot at a time. In the "Saksi Mata" short story collection, the author often criticizes the problem of warfare and government authority. In the New Order era, Indonesia experienced many social problems such as the rejection of the Indonesian government on the will of East Timor who wanted to break away from Indonesia, which resulted in many rebellions from individuals and groups who wanted themselves to be independent. The Indonesian army plunged directly to overcome the rebellion to overcome the rebellion there and it was there that many Indonesian soldiers ignored humanitarian and human rights issues.

Furthermore, the tendency of each author to use the form of delivery of criticism is certainly different. Each author has his own style in utilizing terms or building a structure of sentences that describe social problems that occur in community life, especially authors in short stories Witnesses Short Story. This is in accordance with the opinion of Hasanuddin WS (in Banua, 2007: 171) which says that the views and attitudes of the author determine the failure or failure of an author in utilizing elements of language as an aspect of determining the meaning of the literary work it produces. 


\section{Conclusion}

Based on the results and discussion of social criticism in a collection of short stories "Saksi Mata" by Seno Gumira Ajidarma can be concluded that the most dominant issues in the short story collection "Saksi Mata" Seno Gumira Ajidarma is a crime and warfare. While the form of delivery of criticism by the authors is the most dominant form of delivery cynically.

This finding is very important to understand and be guided by teenagers, young people, and education that will study new sciences that benefit all of society, especially students of English Literature Indonesia who deals with words and language.

\section{Reference}

[1] Y. Asri, “ANALISIS SOSIOLOGIS CERPEN 'SI PADANG' KARYA HARRIS EFFENDI THAHAR,” Humaniora, vol. 23, no. 3, pp. 245-255, 2011.

[2] Y. Asri, Zulfadli, and M. I. Nst., "Pendegradasian Kemanusiaan dalam Novel-novel Pengarang Etnis Minangkabau," Humanus, vol. 15, pp. 216-225, 2016.

[3] S. D. Damono, Sosiologi Sastra: Sebuah Pengantar Singkat. Jakarta: Pusat Pembinaan dan Pengembangan Bahasa Departemen Pendidikan dan Kebudayaan, 1984.

[4] R. Maryunita and A. C. Tamsin, "PROFIL KEMANUSIAAN DALAM ANTOLOGI CERPEN PILIHAN KOMPAS 2010,” J. Pendidik. Bhs. dan Sastra Indones., vol. 1, pp. 461-469, 2012.

[5] A. Sofia, "Hegemoni Kriteria Estetik: Tinjauan Sosiologi Sastra Atas Cerpen Pilihan Kompas dan Cerpen Kompas Pilihan,” J. Sosiol. Reflektif, vol. 9, no. 2, pp. 191-212, 2015.

[6] B. H. Viko, "Kritik Sosial dalam Cerpen Kompas Edisi Januari 2012," J. Pendidik. Bhs. dan Sastra Indones., vol. 1, no. 2, pp. 164-240, 2013.

[7] Azwar, "Perlawanan Sastra dalam Cerpen Koran Indonesia," Dialektika, vol. 1, no. 1, pp. 21-46, 2014.

[8] A. D. S. Krissandi, "Cerpen-cerpen Kompas 1970-1980 dalam Hegemoni Negara Orde Baru (Analisis Wacana Kritis).," Poetika, vol. 2, no. 1, pp. 26-35, 2014.

[9] P. F. Setyatmoko, "Penyimpangan Sosial dalam Novel Dunia Karya Nur Sutan Iskandar, Seloka," J. Pendidik. Bhs. dan Sastra Indones., vol. 6, no. 3, pp. 307-313, 2017.

[10] F. Harizadika, "Konflik Sosial dalam Kumpulan Cerpen Perempuan Bawang," J. Pendidik. Bhs. dan Sastra Indones., vol. 1, no. 1, pp. 339-425, 2012.

[11] I. B. P. Manuaba, "Novel-novel Pramoedya Ananta Toer: Refleksi Pendegradasian dan Interpretasi Makna Perjuangan Martabat Manusia," Humaniora, vol. 15, pp. 276284, 2003.

[12] S. G. Ajidarma, "Seno Gumira Ajidarma," Wikipedia, 2017. [Online]. Available: https://id.wikipedia.org/w/index.php?title=Seno_Gumira_Ajidarma\&oldid=13151746.

[13] A. Zamzuri, "Cerpen 'Matinya Seorang Penari Telanjang' Karya Seno Gumira Ajidarma Dalam Perspektif Subjek Slavoj Žižek,” Aksara, vol. 30, no. 1, pp. 1-16, 2018. 